\title{
УРОЖЕНЕЦ ЛАТВИИ В. Ф. ГРУБЕ
}

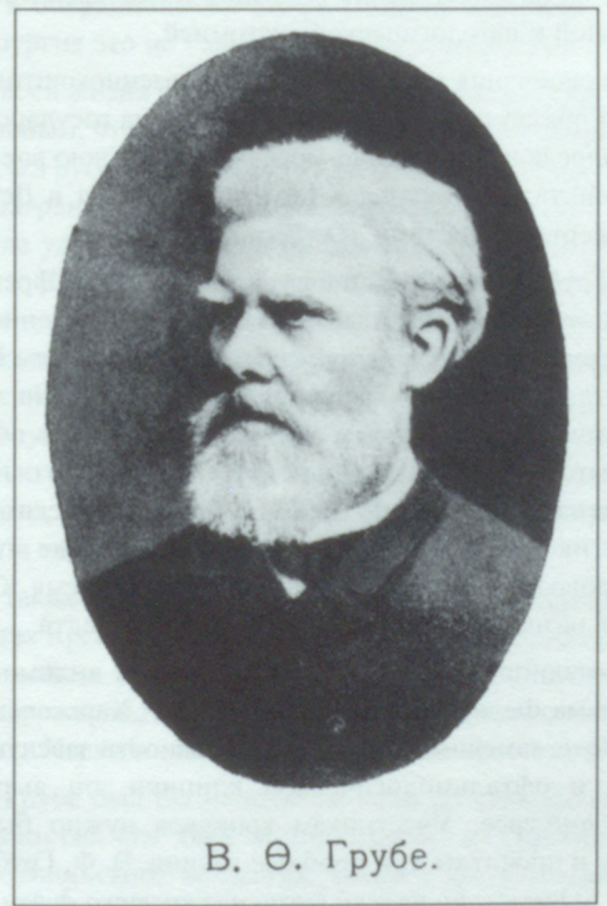

В. Ф. Грубе (1827-1898)

В 2002 г. исполняется 175 лет со рождения выдающегося ученого-хирурга Вильгельма Федоровича Грубе. Он родился 30 мая 1827 г. в селе Нейгут (ныне - Вецумниеки) Курляндской губернии. О сословном положении его родителей сведения не сохранились, но первый биограф В. Ф. Грубе пишет, что родился он в «бедной семье». В 1845 г., после окончания Рижской 
гимназии, поступает в Дерптский (ныне Тартуский) университет на богословский факультет, однако уже через год переходит на медицинскй факультет, решив посвятить себя медицине. Университет в Дерпте переживает тогда годы своего подъема. На медицинском факультете преподавали такие видные ученые как фармаколог Р. Бухгейм, физиолог Г.-Ф. Биддер, преемник Н. И. Пирогова по кафедре теоретической и практической хирургии Г. Ф. Адельман. Уже в студенческие годы у В. Ф. Грубе возникает интерес к хирургии. В 1849-1850 гт. исполняя обязанности ординатора в хирургической и глазной клинике, которой в это время по совместительству заведует проф. Г. Ф. Адельман, он начинает делать операции и одновременно усердно занимается нормальной и патологической анатомией.

В 1850 г. после окончания университета, как казеннокоштньй воспитанник, В. Ф. Грубе был обязан несколько лет отслужить на государственной службе и в 1850 г. его определяют в военно-морской флот. Свою военную службу он начинает в Кронштадте и оттуда, в 1851 г., приезжает в Дерпт для защиты докторской диссертации на тему «De hernia ischiadica».

В 1852 г. В. Ф. Грубе был назначен в качестве лекаря на фрегат «Камчатка» и на нем совершает двухлетнее плавание. После возвращение из плавания он ординатор, а затем заведуюший хирургическим отделением Кроншталтского морского госпиталя. Он много оперирует, но одновременно занимается патологической анатомией. Результатом этих занятий явилась обширная коллекция патологоанатомических препаратов. В 1854-1856 гт. по предписанию медицинского департамента В. Ф. Грубе проводит с морскими врачами практические занятия на трупах, он изготовляет также гистологические препараты и проводит их микроскопирование. Во время Крымской войны В. Ф. Грубе был назначен главным хирургом Кроншталта.

Однако военно-медицинская деятельность, по всей видимости, не удовлетворяла Вильгельма Федоровича и когда в 1858 г. Харьковский университет объявил конкурс на замешение вакантной должности заведующего кафедрой хирургической и офтальмологической клиники, он выражает желание участвовать в конкурсе. Участникам конкурса нужно было представить научную работу и прочитать три пробные лекции. В. Ф. Грубе представил на конкурс работу «О резекции из всей толиины костяка дудки при переломах 6 периоде нагночтельном» и прочитал три лекции по хирургии в Медикохирургической академии. То и другое было высоко оценено и 28 марта 1859 г. он был единогласно избран советом медицинского факультета Харьковского университета экстраординарным, а позднее и ординарным профессором по кафедре оперативной хирургической клиники.

Начиная свою научно-педагогическую деятельность в Харькове, в актовой речи произнесенной в 1864 г., В. Ф. Грубе говорил: «Клинический преподаватель должен с собой принести прилежанье и постоянную деятельность, 
чтобы тем возбудить подражсанье. Он должсен заниматься своим предметам с любобью к самой науке и тицательно заботиться развить в своих слуиателях ясное знание и исполнение». Он проработал в Харькове 39 лет и до конца своих дней свято следовал этому предписанию.

В. Ф. Грубе был прекрасным оператором, с любовью относящимся к своим больным, и талантливым педагогом. Как пишет его биограф, студенческая аудитория воодушевляла его и действовала на него как-то особенно во3буждаюшим образом. Даже дряхлым стариком, после перенесенной в 1893 г. тяжелой болезни, он совершенно преображался и молодел, когда входил в аудиторию или в операционную. Современники говорили, что В. Ф. Грубе доказал, что хирургия это не только наука, но и искусство.

На протяжении всей жизни он совершенствовал свое мастерство и постоянно следил за всем новым, что происходило в избранной им специальности. В октябре 1860 г. В.Ф.Грубе обратился с ходатайством о командировании его с научной целью заграницу в каникулярное время с 1 мая по 1 сентабря $1861 \mathrm{r}$. Ero просьба была удовлетворена, и он повторил поездки еще в 1862, 1867 , 1873 и 1875 гг. За это время он посетил все известные кафедры и хирургические клиники Австрии, Англии, Германии, Франции. Причем его интересовал не только его любимый предмет - хирургия, но и все новое, что происходило в области офтальмологии, гинекологии, ортопедии, ларингологии и даже внутренних и нервных болезней. Его коллеги поражались его осведомленностью во всех областях клинической медицины и не случайно, при необходимости, поручали В. Ф. Грубе замешать заведуюших акушерской клиникой (1862) и терапевтической клиникой (1872).

Он не упускал также возможности познакомиться с военной медициной и работал в лазаретах Красного Креста во время франко-прусской войны 1870 г. и русско-турецкой войны 1877-1878 гт. Во время этой войны он заведовал дивизионным лазаретом под Плевной, а затем временным госпиталем в Систове, а по возвращению в Харьков - госпиталем Красного Креста для тяжело раненых.

Рассказ о В. Ф. Грубе был бы неполным, если не упомянуть о его общественной деятельности. Он был инициатором и главным учредителем Харьковского медицинского общества, которое он возглавлял как председатель с 1864 по 1867 и с 1869 по 1889 год. После этого его избрали пожизненно почетным председателем общества. Одновременно он был старшим врачом Общины Красного Креста и принимал активное участие в различных благотворительных мероприятиях.

Вильгельм Федорович Грубе пользовался всеобщи уважением и признанием. В 1877 г., когда истек срок его 25-летней службы, он по решению факультета был оставлен на службе ещё на 5 лет, а затем его оставляли на службе каждое пятилетие вплоть до дня смерти, которая последовала в мае 1898 года. 
Имя В. Ф. Грубе было известно не только в России, но и далеко за её пределами. О признании его заслуг и трудов свидетельствует тот факт, что когда отмечался 35-летний юбилей научной деятельности В. Ф. Грубе, его поздравляли такие известные ученые как Листер, Вирхов, Шарко, Бильрот, Бергман.

\section{Latvian Born W. F. Grube (Summary) \\ By Konstantin G.Vasilyev}

The article is dedicated to the Latvian born scientist and surgeon Wilhelm Grube, born 175 years ago. After graduating from the University of Dorpat in 1850 he had been serving for several years in the military navy, while during the Crimean war he was head surgeon in Kronstadt. From 1859 to the end of his life he was professor of operative surgery at the Kharkov University. Grube was an outstanding surgeon and scientist as well as an excellent teacher and social worker. He took active part in the work of the Red Cross Society and in many other charity enterprises. He was on of the founders of the medical society in Kharkov, its chairman and finally its honorary chairman.

Константин Георгиевич Васильев, докт. мед. наук

Аб. я. 202

Одесса-144

Украина 65114 